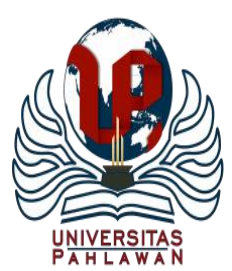

Jurnal Abdidas Volume 2 Nomor 5 Tahun 2021 Halaman 1245 - 1250

JURNAL ABDIDAS

http://abdidas.org/index.php/abdidas

\title{
Edukasi Pentingnya Pendidikan Katekisasi Sidi
}

\author{
Yosefo Gule $^{1 \bowtie}$, Desra Vevalosa Ginting ${ }^{2}$ \\ Universitas Quality Berastagi, Indonesia ${ }^{1,2}$ \\ E-mail : yosefogule@gmail.com ${ }^{1}$, desrabrginting@gmail.com ${ }^{2}$
}

\begin{abstract}
Abstrak
Pendidikan katekisasi sidi merupakan salah satu bentuk pelayanan pendidikan Kristen yang dilakukan oleh gereja, yaitu mengajar atau membimbing seseorang supaya ia melakukan yang diajarkan kepadanya dan juga mengalami pertemuan dan persekutuan dengan Allah secara benar. Namun dalam kenyataannya masih banyak yang menganggap bahwa pengajaran katekisasi sidi hanyalah sebuah formalitas yang dituruti anak-anak oleh sebab tradisi gereja GMI menuntutnya. Sehingga banyak anak-anak yang mengikuti katekisasi sidi hanya sebagai formalitas untuk sekedar memasuki dan menamatkannya secara kebiasaan saja. Oleh sebab itu sangat penting untuk pemberian edukasi kepada anak-anak calon sidi tentang pentingnya pendidikan katekisasi sidi. Sehingga melalui edukasi ini pada akhirnya para anak-anak calon sidi memahami makna dan tujuan pendidikan katekisasi sidi itu sendiri dan dapat mengimplementasikannya dalam diri sendiri, dalam hidup bergereja dan bermasyarakat.
\end{abstract}

Kata kunci: pendidikan, katekisasi Sidi, calon Sidi

\section{Abstract}

Sidi catechism education is one form of Christian education service carried out by the church, namely teaching or guiding someone so that he does what he is taught and also experiences encounter and fellowship with God correctly. However, in reality, many still think that teaching the Sidi catechism is just a formality that children follow because the tradition of the GMI church demands it. So many children who follow the Sidi catechism only as a formality to just enter and finish it habitually. Therefore, it is very important to provide education to the children of Sidi candidates about the importance of Sidi catechism education. So that through this education, in the end the children of the Sidi candidates understand the meaning and purpose of Sidi catechism education itself and can implement it in themselves, in church and community life.

Keywords: education, Sidi catechism, Sidi candidate

Copyright (c) 2021 Yosefo Gule, Desra Vevalosa Ginting

$\triangle$ Corresponding author

Address : Universitas Quality Berastagi

Email : yosefogule@gmail.com

ISSN 2721-9224 (Media Cetak)

DOI : https://doi.org/10.31004/abdidas.v2i5.462

ISSN 2721- 9216 (Media Online) 


\section{PENDAHULUAN}

Pendidikan katekisasi sidi merupakan salah satu bentuk pelayanan pendidikan Kristen yang dilakukan oleh gereja. Istilah katekisasi berasal dari kata kerja bahasa Yunani katekhein yang berarti memberitahukan, menjelaskan atau memberi pengajaran. Melakukan pengajaran menurut kata katekhein bukan hanya ditekankan dalam arti intelektualitas tetapi lebih kepada arti praktis, yaitu mengajar atau membimbing seseorang supaya ia melakukan yang diajarkan kepadanya dan juga mengalami pertemuan dan persekutuan dengan Allah secara baik dan benar. Pendidikan katekisasi sidi juga merupakan sebuah proses pembimbingan dan pengajaran iman yang di percaya, yaitu iman Kristen. Dengan kata lain, katekisasi berfungsi sebagai sarana untuk menumbuhkembangkan dan mendewasakan iman warga dan calon warga jemaat dalam mengaktualisasikan ajaran kristus di tengah-tengah kehidupan sehari-hari (Abineno, 2001).

Namun dalam kenyataannya masih banyak yang menganggap bahwa pengajaran katekisasi sidi hanyalah sebuah formalitas yang dituruti anakanak oleh sebab tradisi gereja GMI menuntutnya. Sehingga banyak anak-anak yang mengikuti katekisasi sidi hanya sekedar memasuki dan menamatkannya secara kebiasaan saja. "Masuk Sidi" adalah peraturan gereja GMI sebagai tanda bahwa seseorang tersebut sah menjadi anggota penuh GMI, jadi patut ditaati, tetapi belum terjadi pertobatan yang sungguh dan belumlah lahir dalam batin mereka keyakinan dan iman yang sejati, sebagaimana teologi John Wesley menekankan hidup baru/lahir baru (Tobing, 2006). Kita mengetahui bahwa pertobatan sejati dan kelahiran baru adalah hal yang penting bagi kehidupan para nara didik katekisasi sidi.

Di sisi lain, pemahaman terhadap kegiatan katekisasi sidi yang melihat peneguhan sidi itu sendiri saja yang menjadi tujuan dan pegangan seterusnya bagi calon-calon anggota GMI penuh (Disiplin GMI 2017, 2017). Pemahaman para katekisasi sidi yang hanya melihat asal saja nanti saya terdaftar menjadi anggota penuh GMI dan memiliki sertifikat peneguhan sidi, maka cukup dan bereslah semuanya, keselamatan saya terjamin, pintu sorga terbuka bagi saya, dan tidak usah kuatir dengan apa-apa lagi termaksud keterlibatan terhadap kegiatan gereja.

Sebagai dampaknya, keberadaan peserta katekisasi sidi yang telah diteguhkan dan telah menjadi anggota penuh gereja tidak jarang menunjukkan bahwa hanya sekitar 20\% yang mau terlibat dalam persekutuan dengan Tuhan dan pelayanan gereja, dan yang lainnya hanya ingin menunjukkan muka di gereja apabila mereka membutuhkan pertolongan gereja untuk nikah, pembaptisan anak, penguburan, dll (Abineno, 2001).

Berdasarkan permasalahan di atas, maka sangat penting edukasi tentang pentinnya pendidikan katekisasi sidi bagi anak-anak calon sidi, sehingga makna mengikuti pendidikan katekisasi sidi tidak hanya sekedar formalitas saja. Melalui edukasi ini, pada akhirnya proses katekisasi dalam kehidupan jemaat/gereja, kita menantikan tuaiannya kelak berupa hadirnya anggota-anggota jemaat baru yang siap untuk mewujudkan persekutuan dengan penuh kasih dan melaksanakan tugas pengutusan berupa kesaksian dan pelayanannya dengan militan dalam ketaatan 
kepada pesan Tuhan Yesus. Dengan demikian, kita tidak hanya menginginkan penambahan jumlah anggota gereja secara kuantitatif, melainkan juga anggota-anggota jemaat baru yang dapat dipertanggungjawabkan secara berkualitas dalam iman dan kehidupan kristennya.

Adapun tujuan dari kegiatan pengabdian masyarakat tentang edukasi pentingnya pendidikan katekisasi sidi ini adalah: (1) Memberikan

Edukasi tentang pentingnya pendidikan katekisasi Sidi; (2) Kepedulian Dosen Universitas Quality Berastagi untuk memberikan Edukasi tentang Pentingnya Pendidikan Katekisasi Sidi bagai calon sidi di GMI Hutahaean; (3) Diharapkan dengan adanya kegiatan ini para peserta calon sidi memahami makna dan tujuan pendidikan katekisasi dilaksanakan dan bukan hanya sebatas formalitas; (4) Melaksanakan Tri Dharma Perguruan Tinggi berupa Pengabdian Kepada Masyarakat.

\section{METODE}

Kegiatan pengabdian masyarakat ini dilakukan dalam bentuk edukasi dengan pemudapemudi jemaat GMI Imamanuel Hutahaean pada hari Sabtu, 18 September 2021, yang dilaksanakan di GMI Immanuel Hutahaean, Kecamatan Laguboti, Kabupaten Tobasa-SUMUT. Program ini dipilih bertujuan untuk meningkatkan pemahaman serta kesadaran pemuda-pemudi calon sidi GMI Immanuel Hutahaean tentaang pentingnnya pendidikan katekisasi sidi. Adapun peserta yang mengikuti kegiatan pengabdian masyarakat ini adalah seluruh pemuda-pemudi calon sidi GMI Immanuel Hutahaean yang berjumlah \pm 60 orang. Kegiatan ini dilakukan dengan menggunakan beberapa tahapan, yaitu survei lokasi sasaran, identifikasi kebutuhan program, persiapan sarana dan prasarana, pelaksanaan dan evaluasi. Kegiatan ini dilaksanakan selama satu hari dan kegiatan ini diakhiri dengan diskusi tanya jawab sebagai evaluasi terhadap tingkat ketercapaian pemahaman pemuda-pemudi calon sidi tentang pendidikan katekisasi sidi.

\section{HASIL DAN PEMBAHASAN}

Kegiatan pengabdian kepada masyarakat yang di lakukan di GMI Immanuel Hutahaean ini adalah memberikan edukasi terkait masalah pendidikan katekisasi sidi.

Pendididikan Katekisasi Sidi. Pendidikan katekisasi sidi merupakan salah satu bentuk pelayanan Pendidikan Agama Kristen yang dilakukan oleh gereja. Istilah katekisasi berasal dari kata kerja bahasa Yunani katekhein yang berarti memberitahukan, menjelaskan atau memberi pengajaran. Melakukan pengajaran menurut kata katekhein bukan hanya ditekankan dalam arti intelektualitas tetapi lebih kepada arti praktis, yaitu mengajar atau membimbing seseorang supaya ia melakukan yang diajarkan kepadanya dan juga mengalami pertemuan dan persekutuan dengan Allah secara baik dan benar. Pendidikan katekisasi sidi juga merupakan sebuah proses pembimbingan dan pengajaran tentang Firman Tuhan dan gereja-Nya. Pendidikan katekisasi sidi berfungsi sebagai sarana untuk menumbuhkembangkan dan mendewasakan iman warga dan calon warga jemaat dalam mengaktualisasikan ajaran kristus di tengah-tengah kehidupan sehari-hari (Abineno, 2001). 
Pentingnya Pendidikan Katekisasi Sidi. Pendidikan Katekisasi Sidi adalah penting di dalam gereja sebabab pendidikan katekisasi sidi adalah pitu gerbang untuk mempersiapkan generasi GMI yang baik dan berkualitas (Gule, 2020). Dalam disiplin GMI, anak-anak yang telah di didik lewat pendidikan katekisasi sidi dan telah menerima peneguhan sidi, maka seseorang tersebut akan menajdi anggota jemaat penuh GMI dan mampu menjalankan tugas dan tanggung jawab sebagai anggota jemaat GMI (Disiplin GMI 2017, 2017). Fondasi dan pengajar Pendidikan Katekisasi Sidi yang baik dan benar akan melahirkan generasi GMI yang baik cerdas, berspiritulitas dan berkuliatas. Melalui Pendidikan katekisasi SIDI gereja sedang mempersiapkan para anak-anak didik untuk terlibat melayani Tuhan lewat gereja-Nya (GMI).

Katekisasi Sidi: Masalah dan Hambatan: (1) masih banyak yang menganggap bahwa pengajaran katekisasi sidi hanyalah sebuah formalitas yang dituruti anak-anak oleh sebab tradisi gereja GMI menuntutnya. Sehingga banyak anak-anak yang mengikuti katekisasi sidi hanya sekedar memasuki dan menamatkannya secara kebiasaan saja. "Masuk Sidi" adalah peraturan gereja GMI sebagai tanda bahwa seseorang tersebut sah menjadi anggota penuh GMI, jadi patut ditaati, tetapi belum terjadi pertobatan yang sungguh dan belumlah lahir dalam batin mereka keyakinan dan iman yang sejati, sebagaimana teologi John Wesley menekankan hidup baru/lahir baru (Tobing, 2006). Pertobatan sejati dan kelahiran baru adalah hal yang penting bagi kehidupan para nara didik katekisasi sidi; (2) Di sisi lain, pemahaman terhadap kegiatan katekisasi sidi yang melihat peneguhan sidi itu sendiri saja yang menjadi tujuan dan pegangan seterusnya bagi calon-calon anggota GMI penuh (Disiplin GMI 2017, 2017). Pemahaman para katekisasi sidi yang hanya melihat asal saja nanti saya terdaftar menjadi anggota penuh GMI dan memiliki sertifikat peneguhan sidi, maka cukup dan bereslah semuanya, keselamatan saya terjamin, pintu sorga terbuka bagi saya, dan tidak usah kuatir dengan apa-apa lagi termaksud keterlibatan terhadap kegiatan gereja.

Sebagai dampaknya, tidak ada pertobatan dan pembaharuan iman di dalam diri anak-anak yang telah menerima peneguhan sidi. Keberadaan peserta katekisasi sidi yang telah diteguhkan dan telah menjadi anggota penuh gereja tidak jarang menunjukkan bahwa hanya sekitar $20 \%$ yang mau terlibat dalam persekutuan dengan Tuhan dan pelayanan gereja (Abineno, 2001) (SM, P3MI, P2MI, PWMI, Ibadah Evangelisasi, Ibadah Komsel, dll - Survei Terhadapa Anaka-anak yang sudah di SIDI). Hadir ke gereja apabila mereka membutuhkan pertolongan gereja untuk nikah, pembaptisan anak, penguburan. Kurang Mencintai Gereja-Nya. Generasi Methodist bisa menjadi memburuk.

Upaya meningkatkan kualitas katekisasi sidi: Memberikan edukasi makna dan tujuan katekisasi sidi ialah mengajar atau membimbing seseorang supaya anak-anak percaya kepada Yesus Kristus sebagai Tuhan dan Juru selamat mereka dan dengan itu mendapat persekutuan dengan Dia. Selain itu Pendidikan katekisasi sidi juga bertujuan untuk membina anggota jemaat untuk menyadari tugas mereka di dalam Gereja dan kemudian mempertanggujawabkan iman mereka di dalam 
dunia. Dampak yang diharapkan dari pendidikan katekisasi sidi ialah: anak yang akan menerima peneguhan sidi telah mengalami Pertobatan dan pembaharuan Iman. Semakin Meneguhkan Imannya kepada Tuhan Yesus. Percaya kepada Yesus Kristus sebagai Tuhan dan JuruselamatNya. Mengabil bagian dan Terlibat dalam pelayan gereja baik SM, P3MI, P2MI, PWMI, Ibadah Umum, Evangelisasi, Kelompok Sel, dll. Mejadi Penerus Kristen yang baik melalui Gereja Methodist, Menjadi Teladan dalam perkataan, tingkah laku, kasih, kesetian dan kecucian (1 Tes. 4:12). Pemuda Pemudi GMI makin bertambah Besar dan Bertambah Hikmatnya dan besarnya dan makin dikasihi oleh Allah dan Manusia" (Luk. 2:52).

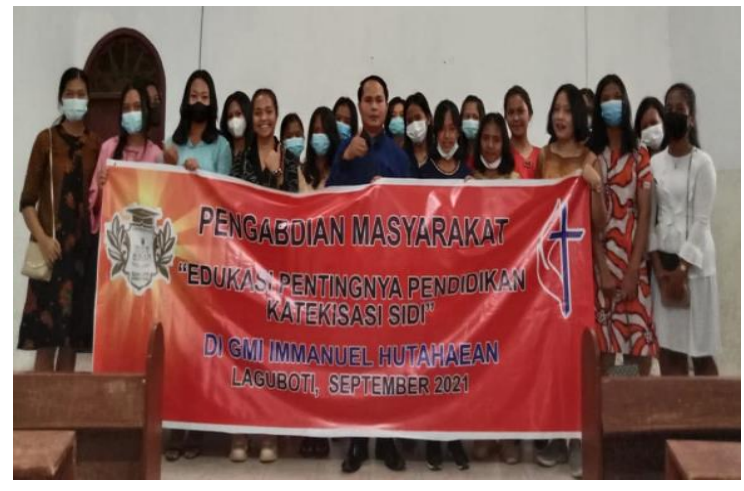

Gambar 1. Hasil Edukasi Pengabdian

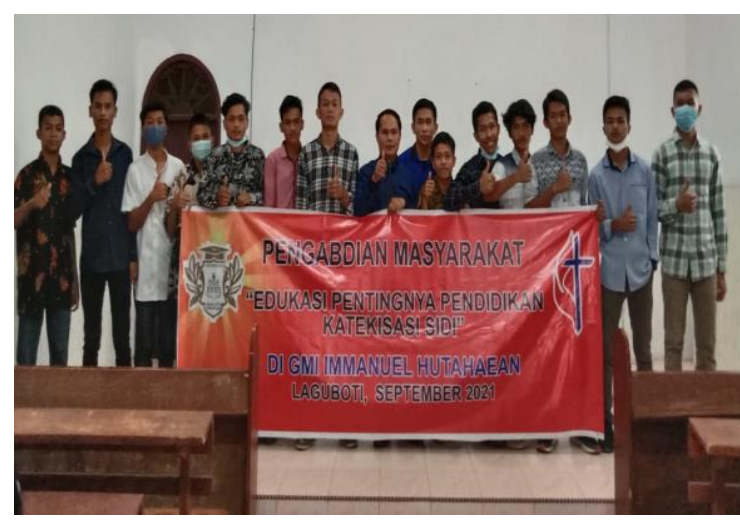

Gambar 2. Masyarakat di GMI Immanuel Hutahaean

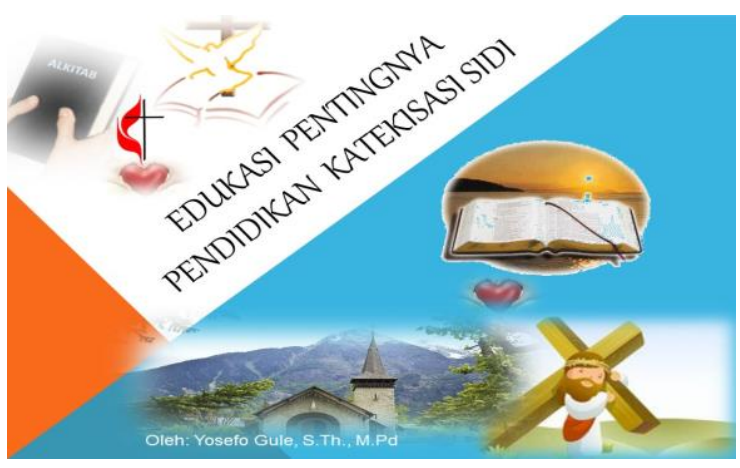

Gambar 3. Tampilan Presentase Sosialisasi

Hasil sosialisasi pengabdian masyarakat ini berjalan lancar, yang disampaikan lewat pemaparan materi dan dilanjutkan dengan diskusi tanya jawab yang sangat antusias di ikuti oleh peserta, hasil menunjukkan bahwa tingkat pemahaman pemuda-pemudi calon sidi meningkat, dari yang tidak tahu menjadi tahu terkait pentingnya pendidikan kaetekisasi sidi. Kegiatan pengabdian masyarakat ini sangat bermanfaat bagi pemuda-pemudi calon sidi GMI Immanuel Hutahaean, sebab mereka mendapat pemahaman, motivasi, edukasi, persuasi, untuk memberdayakan mereka untuk tetap mengalami pertobatan dan pembaharuan Iman. Semakin Meneguhkan Imannya kepada Tuhan Yesus. Percaya kepada Yesus Kristus sebagai Tuhan dan JuruselamatNya. Mengabil bagian dan Terlibat dalam pelayan gereja baik SM, P3MI, P2MI, PWMI, Ibadah Umum, Evangelisasi, Kelompok Sel, dll. Mejadi Penerus Kristen yang baik melalui Gereja Methodist, Menjadi Teladan dalam perkataan, tingkah laku, kasih, kesetian dan kecucian (1 Tes. 4:12). Pemuda Pemudi GMI makin bertambah Besar dan Bertambah Hikmatnya dan besarnya dan makin dikasihi oleh Allah dan Manusia" (Luk. 2:52). Selain itu manfaat kegiatan ini bagi pemuda-pemudi calon sidi GMI Immanuel 
Hutahaean ialah memahami makna dan tujuan pendidikan katekisasi sidi itu sendiri dan dapat mengimplementasikannya dalam diri sendiri, dalam hidup bergereja dan bermasyarakat.

\section{SIMPULAN}

Pelaksanaan kegiatan pengabdian masyarakat di GMI Immanuel Hutahaean, Desa Simatibung-Hutahaean, Kec. Laguboti, Kab. Tobasa - SUMUT berjalan dengan baik dan sesuai target yang di harapkan. Lewat sosialisasi ini, Dampak yang diharapkan dari pendidikan katekisasi sidi ialah: anak yang akan menerima peneguhan sidi telah mengalami Pertobatan dan pembaharuan Iman. Semakin Meneguhkan Imannya kepada Tuhan Yesus. Percaya kepada Yesus Kristus sebagai Tuhan dan JuruselamatNya. Mengabil bagian dan Terlibat dalam pelayan gereja baik SM, P3MI, P2MI, PWMI, Ibadah Umum, Evangelisasi, Kelompok Sel, dll. Mejadi Penerus Kristen yang baik melalui Gereja Methodist, Menjadi Teladan dalam perkataan, tingkah laku, kasih, kesetian dan kecucian (1 Tes. 4:12). Pemuda Pemudi GMI makin bertambah Besar dan Bertambah Hikmatnya dan besarnya dan makin dikasihi oleh Allah dan Manusia" (Luk. $2: 52)$.

\section{UCAPAN TERIMA KASIH}

Penulis mengucapkan terimakasih kepada Pimpinan Jemaat GMI Hutahaean, Majelis dan seluruh pemuda-pemudi calon sidi yang telah mengijinkan penulis untuk melakukan sosialisasi di GMI Immanuel Hutahaean.

\section{DAFTAR PUSTAKA}

(2017). Disiplin Gereja Methodist Indonesia Tahun 2017. Badan Disilin Gereja Methodust Indonesia.

Abineno, J. L. C. (2001). Sekitar Katekese Gerejawi. BPK-Gunung Mulia.

Gule, Y. (2020). Sosialisasi Upaya Menjaga Kualitas Kerohanian Anggota Jemaat di Masa Pandemi Covid-19 di GMI Hutahaean. Jurnal Abdidas, 1(3), 231-237. https://doi.org/https://doi.org/10.31004/abdid as.v2i2.245 Copyright

Tobing, R. L. (2006). John Wesley dan PokokPokok Penting dari Pengajarnnya. Citra Sarana Mandiri. 